\title{
The Effect of Low Dose Rate Irradiation on the Swelling of 12\% Cold-Worked 316 Stainless Steel
}

\author{
by \\ T. R. Allen and J. I. Cole \\ Argonne National Laboratory - West \\ Engineering Division \\ Idaho Falls, ID 83403-2528 \\ H. Tsai \\ Argonne National Laboratory \\ Argonne, IL USA \\ S. Ukai, S. Mizuta, and T. Yoshitake \\ Japan Nuclear Cycle Development Institute \\ Ibaraki, Japan

\begin{abstract}
The submitted manuscript has been created by the University of Chicago as Operator of Argonne National Laboratory ("Argonne") under Contract No. W-31-109-ENG-38 with the U.S. Department of Energy. The U.S. Government retains for itself, and others acting on its behalf, a paid-up, nonexclusive, irrevocable worldwide license in said article to reproduce, prepare derivative works, distribute copies to the public, and perform publicly and display publicly, by or on behalf of
\end{abstract} \\ the Government. \\ $9^{\text {th }}$ Int. Conference on Environmental Degradation of \\ Materials in Nuclear Power Systems \\ Newport Beach, CA \\ August 1-5, 1999
}

*Work supported by the U.S. Department of Energy, Materials/Chemistry, Materials Characterization, under Contract W-31-109-ENG-38. 


\section{DISCLAIMER}

This report was prepared as an account of work sponsored by an agency of the United States Government. Neither the United States Government nor any agency thereof, nor any of their employees, make any warranty, express or implied, or assumes any legal liability or responsibility for the accuracy, completeness, or usefulness of any information, apparatus, product, or process disclosed, or represents that its use would not infringe privately owned rights. Reference herein to any specific commercial product, process, or service by trade name, trademark, manufacturer, or otherwise does not necessarily constitute or imply its endorsement, recommendation, or favoring by the United States Government or any agency thereof. The views and opinions of authors expressed herein do not necessarily state or reflect those of the United States Government or any agency thereof. 


\section{DISCLAIMER}

Portions of this document may be illegible in electronic image products. Images are produced from the best available original document. 
The Effect of Low Dose Rate Irradiation on the Swelling of $12 \%$ Cold-Worked 316 Stainless Steel.

T. R. Allen and J. I. Cole

Argonne National Laboratory-West

Idaho Falls, ID USA

H. Tsai

Argonne National Laboratory

Argonne, IL USA

S. Ukai, S. Mizuta, and T. Yoshitake

Japan Nuclear Cycle Development Institute

Ibaraki, Japan

-In pressurized water reactors (PWRs), stainless steel components are irradiated at temperatures that may reach $400^{\circ} \mathrm{C}$ due to gamma heating. If large amounts of swelling $(>10 \%)$ occur in these reactor internals, significant swelling related embrittlement may occur. Although fast reactor studies indicate that swelling should be insignificant at PWR temperatures, the low dose rate conditions experienced by PWR components may possibly lead to significant swelling. To address these issues, JNC and ANL have collaborated to analyze swelling in 316 stainless steel, irradiated in the EBR-II reactor at temperatures from $376-444^{\circ} \mathrm{C}$, at dose rates between $4.9 \times 10^{-8}$ and $5.8 \times 10^{-7} \mathrm{dpa} / \mathrm{s}$, and to doses of $56 \mathrm{dpa}$. For these irradiation conditions, the swelling decreases markedly at temperatures less than approximately $386^{\circ} \mathrm{C}$, with the extrapolated swelling at $100 \mathrm{dpa}$ being around $3 \%$. For temperatures greater than $386^{\circ} \mathrm{C}$, the swelling extrapolated to $100 \mathrm{dpa}$ is around $9 \%$. For a factor of two difference in dose rate, no statistically significant effect of dose rate on swelling was seen. For the range of dose rates analyzed, the swelling measurements do not support significant (>10\%) swelling of 316 stainless steel in PWRs.

\section{Introduction}

Garner et al. [1] has predicted that swelling related embrittlement may be a concern in pressurized water reactor (PWR) components made of 304 and 316 stainless steel, where thicker components may reach temperatures up to $400^{\circ} \mathrm{C}$ [2]. Components reaching swelling levels greater than $10 \%$ would become brittle and vulnerable to failure under seismic or thermal shocks or under slow strain rate conditions. Although fast reactor studies do not predict large amounts of swelling at PWR temperatures, the lower displacement rates experienced in PWRs may cause a larger swelling per dpa than would be predicted from high-flux fast reactor data.

The dose rates for typical PWR components range from about $1.4 \times 10^{-7} \mathrm{dpa} / \mathrm{s}$ for components in the inner core region to $1.4 \times 10^{-10} \mathrm{dpa} / \mathrm{s}$ for the core barrel (these displacement rates are based fast neutron fluences from [3] converted to dpa using $0.7 \times 10^{21} \mathrm{n} / \mathrm{cm}^{2} \mathrm{~s}=1$ dpa [4]). To provide data relevant to light water reactor component aging, a large quantity of hexagonal duct material, made of 304 and 316 stainless steel with a thickness of approximately $1 \mathrm{~mm}$, was retrieved from the EBR-II reactor for testing. Swelling was measured in 316 stainless steel irradiated at dose rates from $4.9 \times 10^{-8}$ to $5.8 \times 10^{-7} \mathrm{dpa} / \mathrm{s}$, comparable to those of PWR components. The steel was irradiated at temperatures from $376-444^{\circ} \mathrm{C}$ to doses from about 9 dpa to $56 \mathrm{dpa}$. Swelling as a function of dose, dose rate, and temperature are analyzed to estimate if swelling of PWR components made of 316 stainless steel will reach levels of concern.

\section{Experiment}


Density was measured on forty samples of $12 \%$ cold worked (CW) 316 stainless steel irradiated in the EBR-II reactor. The samples were taken from hex cans, the structural components used to hold stainless steel reflectors. Twenty $1.91 \mathrm{~cm}$ diameter density coupons were punched from each of two subassemblies (designated U9861 and U9922), providing for a total of forty density measurements. The density samples were taken from locations irradiated at temperatures from $376-444^{\circ} \mathrm{C}$, at dose rates between $4.9 \times 10^{-8}$ and $5.8 \times 10^{-7} \mathrm{dpa} / \mathrm{s}$, to doses of $56 \mathrm{dpa}$. The dose rate for U9861 is twice that for similar positions on U9922. The density of each coupon was measured five times and the average density is reported.

\section{Results}

The density measurements for each sample, along with the corresponding flat (a flat is a side of the hex can), position, temperature, dose, and dose rate are reported in Tables I and II. The uncertainty in these density measurements is $0.02 \mathrm{~g} / \mathrm{cm}^{3}$.

Unirradiated material was not available from the same lot of 316 SS used in U9861 and U9922, so the unirradiated density was measured on samples of $12 \% \mathrm{CW} 316$ hex can from a different lot of the same nominal composition. The swelling was calculated from this unirradiated density (7.938 $\mathrm{g} / \mathrm{cm}^{3}$ ). Figure 1 plots the best cubic polynomial fit of the U9922 swelling measurements, along with the $95 \%$ confidence limits on the cubic fit. Also on figure 1 are the density measurements from U9861. All of the U9861 swelling measurements fall within the limits of the U9922 swelling curve. For both hex cans, the density increases at low dose (to approximately $20 \mathrm{dpa}$ ) before decreasing. Densification of 316 stainless steel at low dose has been noted in previous measurements of irradiated 316 stainless steel [5].

\section{Discussion}

For austenitic stainless steels, the swelling rate typically increases with dose until reaching a final steady-state swelling rate of approximately $1 \% / \mathrm{dpa}$ [6]. The swelling of reactor components at low swelling (prior to the swelling rate reaching the steady-state of $1 \% / \mathrm{dpa}$ ) has typically been modeled using a power law formulation [7-8]:

$$
\frac{\Delta \mathrm{V}}{\mathrm{V}}=\mathrm{AD}^{\mathrm{n}}
$$

where $\mathrm{D}$ is the irradiation dose. The swelling exponent $\mathrm{n}$ describes the rate at which the swelling approaches the $1 \% /$ dpa rate. The variable $A$ describes the temperature dependence of the swelling. Both $\mathrm{A}$ and $\mathrm{n}$ are functions of material and irradiation conditions (temperature and dose rate). Using a power law description, a log-log plot of swelling versus dose provides a simple means of differentiating swelling rate by comparing the exponents n. For 304 stainless steel, an exponent of $\mathrm{n}=2$ has been measured for the temperature range of $393-542^{\circ} \mathrm{C}$ [8]. For 316 stainless steel irradiated at $383^{\circ} \mathrm{C}$ in EBR-II, the measured exponent ranges from 1.67 to 2.01 and for 316 irradiated in HFIR, the exponent is approximately 1.5 [7]. The exponent is higher for void (EBRII) swelling and less for helium bubble or mixed helium bubble (HFIR) swelling [7].

The effect of experimental variables (temperature, dose, and dose rate) on the swelling of irradiated $12 \% \mathrm{CW} 316$ stainless steel can be analyzed using a power law description. To use a power law description, the data must be adjusted for densification, specifically: 
-the average density was calculated for any densities greater than the density of unirradiated 316 stainless steel $\left(7.938 \mathrm{~g} / \mathrm{cm}^{3}\right)$. For U9861, eight samples had densities greater than $7.938 \mathrm{~g} / \mathrm{cm}^{3}$. The average density was $7.953 \mathrm{~g} / \mathrm{cm}^{3}$. For $U 9922$, five samples had densities greater than $7.938 \mathrm{~g} / \mathrm{cm}^{3}$. The average density was also $7.953 \mathrm{~g} / \mathrm{cm}^{3}$. Since the average density for samples that underwent densification was the same for both hex cans, swelling was calculated from the point of maximum density, which was assumed to be $7.953 \mathrm{~g} / \mathrm{cm}^{3}$ :

$$
\frac{\Delta V}{V}=100 * \frac{7.953-\rho}{\rho}
$$

-to analyze only samples that were swelling, samples with doses less than 20 dpa were not included in the power law analysis.

\section{Swelling as a function of temperature and dose}

Swelling versus dose is plotted on log-log plots in figure 2, using the data from U9861 and U9922 corrected for densification. The slope of these graphs is equal to the exponent $n$ in the power law relationship. Since swelling is known to be a function of irradiation temperature [6], the swelling measurements were divided into three temperature groups, $\left(376-386^{\circ} \mathrm{C}, 386-400^{\circ} \mathrm{C}, 400-444^{\circ} \mathrm{C}\right)$.

For temperatures greater than $386^{\circ} \mathrm{C}$, the swelling exponent is $3.2-3.3$. The swelling exponent for temperatures less than $386^{\circ} \mathrm{C}$ is 1.6 . At higher temperatures, the swelling approaches $1 \% / \mathrm{dpa}$ at a much faster rate than at lower temperatures. For temperatures greater than $386^{\circ} \mathrm{C}$, the fitted power law predicts that swelling reaches $1 \% / \mathrm{dpa}$ at about $180 \mathrm{dpa}$ and at $100 \mathrm{dpa}$, the predicted swelling is around $9 \%$. For temperatures between $376-386^{\circ} \mathrm{C}$, the fitted swelling is only $2.8 \%$ at 100 dpa. Recall that the extrapolated swelling was calculated using the difference between the measured swelling and the fully densified density $\left(7.953 \mathrm{~g} / \mathrm{cm}^{3}\right)$. Therefore, the swelling calculated at 100 dpa as compared to the unirradiated hex can is slightly less ( $8.8 \%$ for temperatures greater than $386^{\circ} \mathrm{C}$ and $2.6 \%$ for temperatures between $376-386^{\circ} \mathrm{C}$ ).

The difference in swelling behavior as a function of temperature can also be seen in figure 4 . The swelling measurements (not corrected for densification) as a function of dose are plotted, with the data separated into three groups: $\left(376-386^{\circ} \mathrm{C}, 386-400^{\circ} \mathrm{C}, 400-444^{\circ} \mathrm{C}\right)$. The curves are the best fit second order polynomials to the swelling measurements. The higher temperature samples undergo greater densification with a faster swelling rate at doses above $30 \mathrm{dpa}$. The lower temperature samples undergo little densification with a slower swelling rate at doses above 30 dpa.

\section{Swelling as a function of dose rate}

The dose rate varies by a factor of two between hex cans. To determine if a dose rate effect exists, the swelling measurements for temperatures between 386 and $444^{\circ} \mathrm{C}$ are plotted in figure 4 . In figure 4, the best fit power law equation for U9922 is plotted along with the $95 \%$ confidence limits on the fit. The swelling measurements for U9861 are also plotted in figure 4 and all fall within the limits of the U9922 measurements. Therefore, no significant dose rate effect is evident for 316 irradiated at temperatures between 386 and $444^{\circ} \mathrm{C}$ with dose rates between $1.4 \times 10^{-7}$ and $5.8 \times 10^{-7}$ $\mathrm{dpa} / \mathrm{s}$.

For the $376-386^{\circ} \mathrm{C}$ measurements, the best fit power law equation for U9922 is plotted along with the $95 \%$ confidence limits on the fit in figure 5 . The swelling measurements for U9861 are also plotted. The swelling measurements for U9861 fit within the bounds of the U9922 measurements. 
For this lower temperature data, there are fewer measurements, with greater scatter, leading to wider confidence limits.

Porter [9] has shown that for 304 stainless steel irradiated at $390^{\circ} \mathrm{C}$ at dose rates between $2 \times 10^{-7}$ and $5 \times 10^{-7} \mathrm{dpa} / \mathrm{s}$ that the displacement rate has a significant effect on the amount of swelling. In this work at similar temperatures and similar dose rates, no statistically significant displacement rate effect on swelling was evident in 316 stainless steel.

The lack of dependence of swelling on dose rate at these temperatures is consistent with the measurements of Seran and Dupouy [10]. In their work, annealed 316 stainless steel was irradiated in the RAPSODIE reactor at temperatures of 450,500 , and $550^{\circ} \mathrm{C}$. At 500 and $550^{\circ} \mathrm{C}$, a displacement rate effect on swelling was seen, with higher displacement rates leading to longer transient swelling and less swelling for a fixed dose. The difference was smaller at $500^{\circ} \mathrm{C}$ than at $550^{\circ} \mathrm{C}$. At $450^{\circ} \mathrm{C}$, no effect of displacement rate was discernible.

Even though no statistically significant effect of dose rate is evident in this study, the samples irradiated at a lower dose rate (U9922) do show greater swelling (see figures 4 and 5). Figure 6 plots the swelling for six different pairs of samples chosen to have similar irradiation temperature and dose, but differing in dose rate by a factor of two. In each case, the sample irradiated with the lower rate shows greater swelling. In all but one case, the difference in swelling is less than the experimental uncertainty. This figure indicates that swelling may vary significantly with dose rate, but a wider range of dose rates is needed to show a statistically significant effect.

To investigate a wider range of dose rate, the swelling measurements from an EBR-II control rod thimble can be compared to the swelling from U9922 and U9861. This thimble (designated CRTH-31) was irradiated in row five of EBR-II at a peak dose rate of $8.5 \times 10^{-7} \mathrm{dpa} / \mathrm{s}$, about three times the dose rate of U9922 and 1.5 times that of U9861. The thimble, which was irradiated to a peak dose of $80 \mathrm{dpa}$, was also $12 \%$ cold-worked 316 stainless steel, although not from the same lot as U9922 and U9861. The swelling of CRTH-31 is plotted along with the swelling from U9922 and U9861 in figure 7. Even for a difference in dose rate of a factor of three, no discernible difference in swelling exists.

\section{Relation to Swelling in PWRs}

Garner [1] has proposed that large amounts of swelling ( $>10 \%)$ could possibly occur in PWR reactor internals and that this swelling could lead to significant swelling related embrittlement. Foster et al. [7] have extrapolated swelling measurements from 316 stainless steel removed from a PWR and estimated that end-of-life swelling values are probably less than $3 \%$. For dose rates in the range of $4.9 \times 10^{-8}$ and $5.8 \times 10^{-7} \mathrm{dpa} / \mathrm{s}$, the measurements from this study predict that swelling of $12 \% \mathrm{CW} 316 \mathrm{SS}$ will not reach levels of swelling greater than $10 \%$. Using the power law relationships derived in figure 2 , at temperatures between $386^{\circ} \mathrm{C}$ and $444^{\circ} \mathrm{C}$ at dose rates from $1.4 \times 10^{-7}$ and $5.8 \times 10^{-7} \mathrm{dpa} / \mathrm{s}, 316 \mathrm{SS}$ irradiated in EBR-II reaches swelling levels of approximately $9 \%$ at $100 \mathrm{dpa}$. At temperatures less than $386^{\circ} \mathrm{C}$, the swelling rate decreases significantly. Extrapolated swelling for the temperature range of $376-386^{\circ} \mathrm{C}$ reaches only $3 \%$ by $100 \mathrm{dpa}$.

Foster et al. [7] calculated the swelling exponent in 316 stainless steel irradiated in EBR-II at $383^{\circ} \mathrm{C}$ and found values between 1.67 and 2.01 . In this work, the swelling exponent at $376-386^{\circ} \mathrm{C}$ was calculated to be 1.61, similar to that determined by Foster et al. At higher temperatures, the swelling exponent increases significantly. The analysis of the swelling measurements from both studies indicate that the swelling rate for $316 \mathrm{SS}$ is small in the upper temperature range for PWRs.

Foster et al. [7] reported PWR He production to be $5.9 \mathrm{appm} / \mathrm{dpa}$. The hex cans in this study were irradiated in rows 8 and 9 of EBR-II and have an estimated helium production rate of around 0.2 
appm/dpa. A lower helium production rate is expected to lead to bias-driven void growth [11] and larger swelling. Therefore, the EBR-II swelling measurements should provide a conservative estimate of the swelling relative to PWR components.

\section{Conclusions}

The swelling of 316 stainless steel irradiated at temperatures from $376-444^{\circ} \mathrm{C}$, at dose rates from $4.9 \times 10^{-8}$ and $5.8 \times 10^{-7} \mathrm{dpa} / \mathrm{s}$, and to doses up to $56 \mathrm{dpa}$ has been measured. The components analyzed were irradiated at temperatures comparable to the highest temperatures expected in PWR components at PWR relevant dose rates. For these irradiation conditions, the swelling decreases markedly at temperatures less than about $386^{\circ} \mathrm{C}$, with the extrapolated swelling at 100 dpa being only $3 \%$. At temperatures greater than $386^{\circ} \mathrm{C}$, the swelling is larger, with the extrapolated swelling reaching $9 \%$ by $100 \mathrm{dpa}$. The swelling measurements of this study do not support significant swelling (defined as $>10 \%$ ) of 316 stainless steel in PWRs. For a factor of two difference in dose rate, no statistically significant effect of dose rate on swelling is evident.

\section{Acknowledgements}

The authors gratefully acknowledge the efforts of M. E Vaughn, J. P. Webb, E. L. Wood, and the staffs at the Hot Fuels Examination Facility and Analytical Laboratory at ANL-West. Thanks to K. Grimm for performing the dose calculations and to $R$. Jensen for performing the temperature calculations. Work supported under contract W-31-109-Eng-38 with the Department of Energy.

\section{References}

[1] F. A. Garner, L. R. Greenwood, and D. L. Harrod, Proc. 6th Int. Symp. on Environmental Degradation of Materials in Nuclear Power Systems-Water Reactors, The Minerals, Metals, and Materials Society (1994), 783-790.

[2] J. C. Van Duysen, P. Todeschini, and G. Zacharie, "Effects of Neutron Irradiations at Temperatures Below $500^{\circ} \mathrm{C}$ on the Properties of Cold Worked 316 Stainless Steels: A Review," Effects of Radiation on Materials: 16th International Symposium. ASTM STP 1175, A. S. Kumar, D. S. Gelles, R. Nanstad, and E. A. Little, Eds., American Society for Testing and Materials, Philadelphia, 1993.

[3] V. N. Shah and P. E. MacDonald, Aging and Life Extension of Major Light Water Reactor components, (Elsevier, Amsterdam, 1993).

[4] P.L. Andresen, F.P. Ford, S.M. Murphy, and J.M. Perks, Proc. 4th Int. Symp. on Environmental Degradation of Materials in Nuclear Power Systems - Water Reactors, Jekyll Island, GA, August 1989 (NACE, Houston, 1990), 1.

[5] J. L. Straalsund and M. M. Paxton, Nucl. Tech. 13 (1972) 99.

[6] F. A. Garner, Irradiation Performance of Cladding and Structural Steels in Liquid Metal Reactors, in Materials Science and Technology, A Comprehensive Treatment, Vol 10A Nuclear Materials, Eds., R. W. Cahn, P. Haasen, and E. J. Kramer, (VCH Weinheim, 1994).

[7] J. P. Foster, D. L. Porter, D. L. Harrod, T. R. Mager, and M. G. Burke, J. Nucl. Mater, 224 (1995) 207.

[8] J. P. Foster and J. E. Flinn, J. Nucl. Mater. 89 (1980) 99.

[9] D. L. Porter and G. L. Hudman, Transactions, American Nuclear Society (1980) 230.

[10] J. L. Seran and J. M. Dupouy, "The Swelling of Solution Annealed 316 Cladding in RAPSODIE and PHENIX," Effects of Radiation on Materials: Eleventh Conference, ASTM STP 782. H. R. Brager and J. S. Perrin, Eds., American Society for Testing and Materials, 1982, 99. 5-16.

[11] P. J. Maziasz, J. Nucl. Mater. 205 (1993) 118. 
Table I. Density for Samples from Hex Can U9922

\begin{tabular}{|c|c|c|c|c|c|c|}
\hline $\begin{array}{l}\text { Sample } \\
\text { ID }\end{array}$ & Flat & $\begin{array}{l}\text { Distance from Core } \\
\text { Centerline (mm) }\end{array}$ & $\begin{array}{c}\text { Temperature } \\
\left({ }^{\circ} \mathrm{C}\right)\end{array}$ & Dose (dpa) & $\begin{array}{c}\text { Dose Rate } \\
(\mathrm{dpa} / \mathrm{s})\end{array}$ & $\begin{array}{l}\text { Density } \\
\left(\mathrm{g} / \mathrm{cm}^{3}\right)\end{array}$ \\
\hline $\mathrm{N1}$ & 5 & -493 & 372 & $\overline{8.8}$ & $4.90 \mathrm{E}-08$ & 7.944 \\
\hline N2 & 5 & -357 & 376 & 19.3 & $1.07 \mathrm{E}-07$ & 7.928 \\
\hline N3 & 5 & -321 & 377 & 23.7 & $1.31 \mathrm{E}-07$ & 7.921 \\
\hline N4 & 5 & -159 & 386 & 47.2 & $2.61 E-07$ & 7.87 \\
\hline N5 & 5 & -118 & 390 & 51.8 & $2.86 \mathrm{E}-07$ & 7.858 \\
\hline N6 & 5 & -48 & 396 & 55.8 & $3.08 \mathrm{E}-07$ & 7.823 \\
\hline N7 & 5 & -17 & 399 & 55.9 & $3.08 \mathrm{E}-07$ & 7.811 \\
\hline N8 & 5 & 57 & 407 & 51.1 & $2.82 \mathrm{E}-07$ & 7.815 \\
\hline N9 & 5 & 264 & 429 & 24.7 & $1.36 \mathrm{E}-07$ & 7.937 \\
\hline N10 & 5 & 365 & 438 & 14.3 & $7.90 \mathrm{E}-08$ & 7.965 \\
\hline N11 & 5 & 451 & 444 & 8.8 & $4.90 \mathrm{E}-08$ & 7.955 \\
\hline N12 & 4 & -213 & 382 & 32.9 & $1.82 \mathrm{E}-07$ & 7.909 \\
\hline N13 & 4 & -186 & 384 & 36 & $1.99 E-07$ & 7.925 \\
\hline N14 & 4 & -133 & 388 & 41.2 & $2.27 \mathrm{E}-07$ & 7.908 \\
\hline N15 & 4 & 124 & 414 & 35.7 & $1.97 \mathrm{E}-07$ & 7.911 \\
\hline N16 & 4 & 154 & 418 & 32.6 & $1.80 E-07$ & 7.937 \\
\hline N17 & 4 & 292 & 432 & 18.2 & $1.01 \mathrm{E}-07$ & 7.951 \\
\hline N18 & 1 & -398 & 375 & 13.9 & $7.70 \mathrm{E}-08$ & 7.952 \\
\hline N19 & 1 & 21 & 403 & 46.5 & $2.57 \mathrm{E}-07$ & 7.859 \\
\hline $\mathrm{N} 20$ & 1 & 91 & 411 & 41.1 & $2.27 \mathrm{E}-07$ & 7.901 \\
\hline
\end{tabular}


Table II. Density for Samples from Hex Can U9861

\begin{tabular}{|c|c|c|c|c|c|c|}
\hline $\begin{array}{l}\text { Sample } \\
\text { ID }\end{array}$ & Flat & $\begin{array}{l}\text { Distance from Core } \\
\text { Centerline (mm) }\end{array}$ & $\begin{array}{c}\text { Temperature } \\
\left({ }^{\circ} \mathrm{C}\right)\end{array}$ & Dose (dpa) & $\begin{array}{l}\text { Dose Rate } \\
(\mathrm{dpa} / \mathrm{s})\end{array}$ & $\begin{array}{l}\text { Density } \\
\left(\mathrm{g} / \mathrm{cm}^{3}\right)\end{array}$ \\
\hline$\overline{\text { El }}$ & 1 & -267 & 376 & 19.9 & $2.32 \mathrm{E}-07$ & 7.934 \\
\hline $\mathrm{E} 2$ & 1 & -243 & 376 & 23.2 & $2.70 \mathrm{E}-07$ & 7.936 \\
\hline E3 & 1 & -90 & 388 & 46.2 & $5.39 \mathrm{E}-07$ & 7.897 \\
\hline E4 & 1 & -40 & 394 & 49.5 & 5.77E-07 & 7.873 \\
\hline E5 & 1 & -17 & 397 & 49.7 & $5.80 E-07$ & 7.876 \\
\hline E6 & 1 & 61 & 408 & 45.6 & $5.32 E-07$ & 7.874 \\
\hline E7 & 1 & 230 & 430 & 24.5 & $2.86 \mathrm{E}-07$ & 7.967 \\
\hline E8 & 1 & 324 & 439 & 14.9 & $1.73 \mathrm{E}-07$ & 7.956 \\
\hline E9 & 1 & 368 & 442 & 11.7 & $1.36 \mathrm{E}-07$ & 7.959 \\
\hline $\mathrm{E} 10$ & 2 & -292 & 375 & 14.5 & $1.69 \mathrm{E}-07$ & 7.926 \\
\hline $\mathrm{E} 11$ & 2 & -141 & 383 & 31 & $3.62 E-07$ & 7.925 \\
\hline E12 & 2 & -98 & 387 & 35.4 & $4.13 E-07$ & 7.919 \\
\hline $\mathrm{E} 13$ & 2 & -42 & 394 & 38.5 & $4.50 \mathrm{E}-07$ & 7.921 \\
\hline E14 & 2 & 64 & 408 & 35.7 & $4.16 \mathrm{E}-07$ & 7.928 \\
\hline E15 & 2 & 241 & 432 & 19.5 & $2.27 \mathrm{E}-07$ & 7.945 \\
\hline E16 & 2 & 392 & 443 & 9.1 & $1.07 \mathrm{E}-07$ & 7.948 \\
\hline E17 & 5 & -360 & 374 & 9.6 & $1.11 \mathrm{E}-07$ & 7.949 \\
\hline E18 & 5 & -329 & 374 & 11.7 & $1.36 \mathrm{E}-07$ & 7.949 \\
\hline E19 & 5 & 2 & 399 & 39.3 & $4.59 \mathrm{E}-07$ & 7.919 \\
\hline $\mathrm{E} 20$ & 5 & 129 & 417 & 30.7 & $3.58 \mathrm{E}-07$ & 7.948 \\
\hline
\end{tabular}

Figure 1

Figure 2

Figure 3

Figure 4

Figure 5

Figure 6

Figure 7 


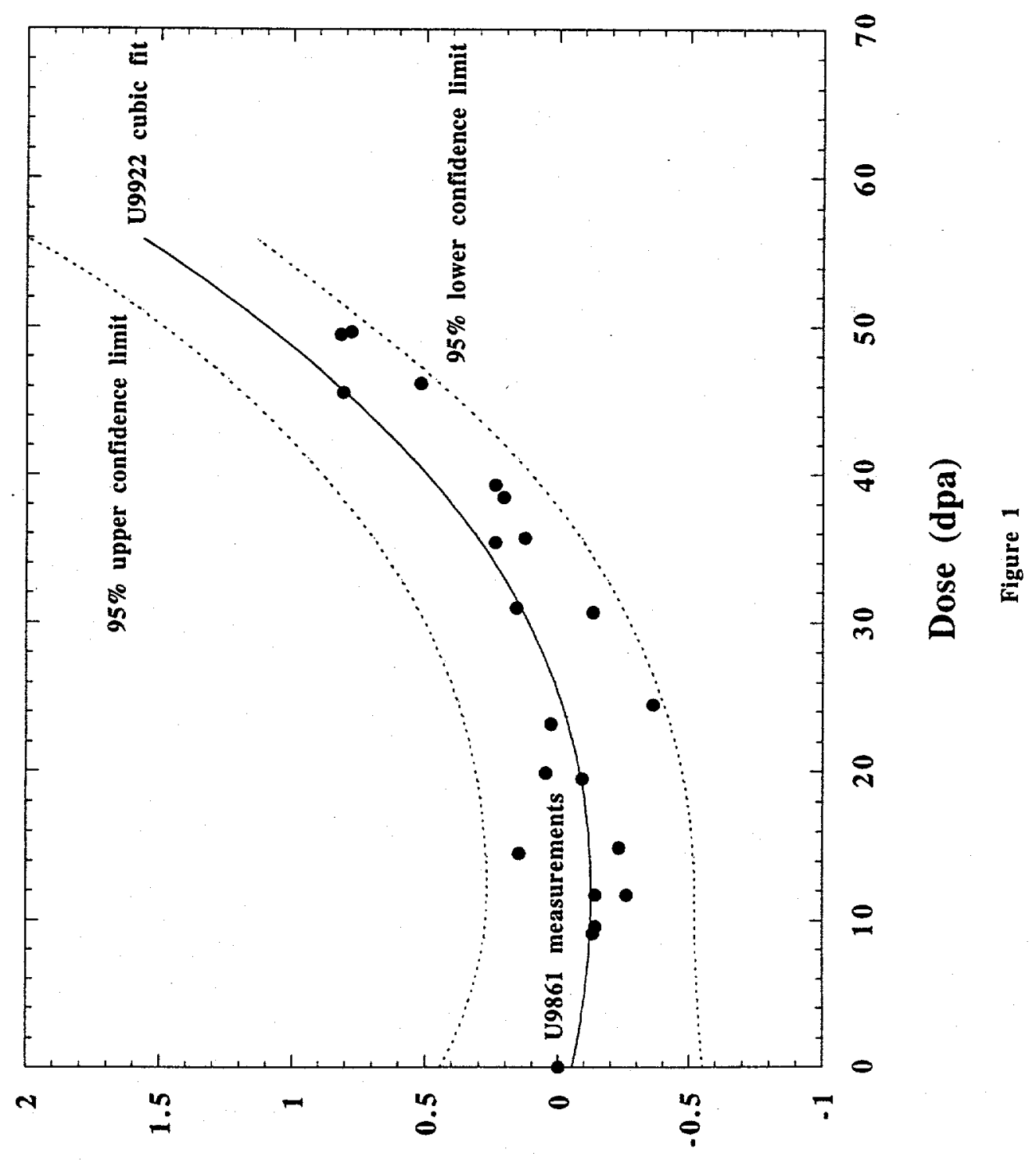

(\%) 8ีน!||วMS 


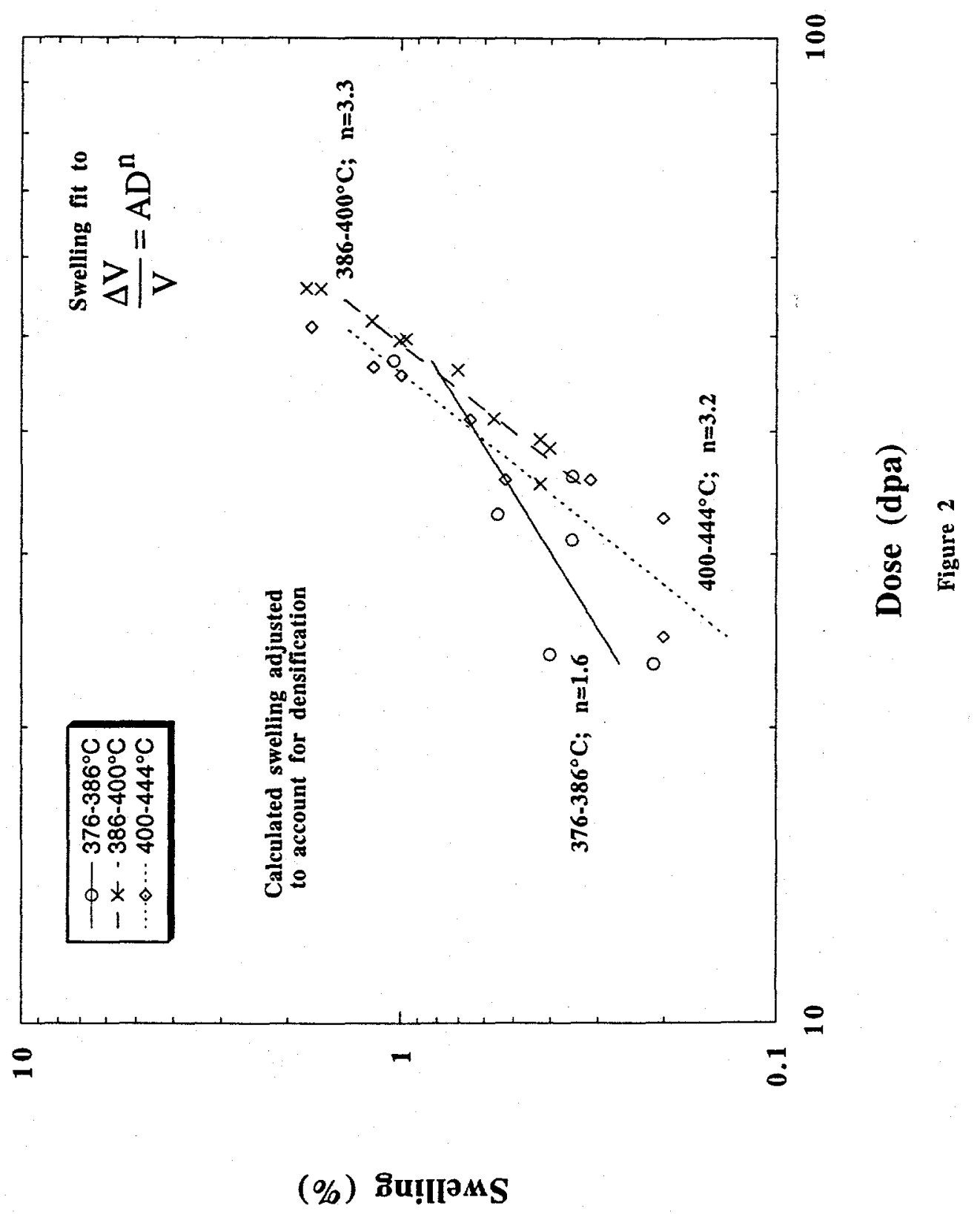




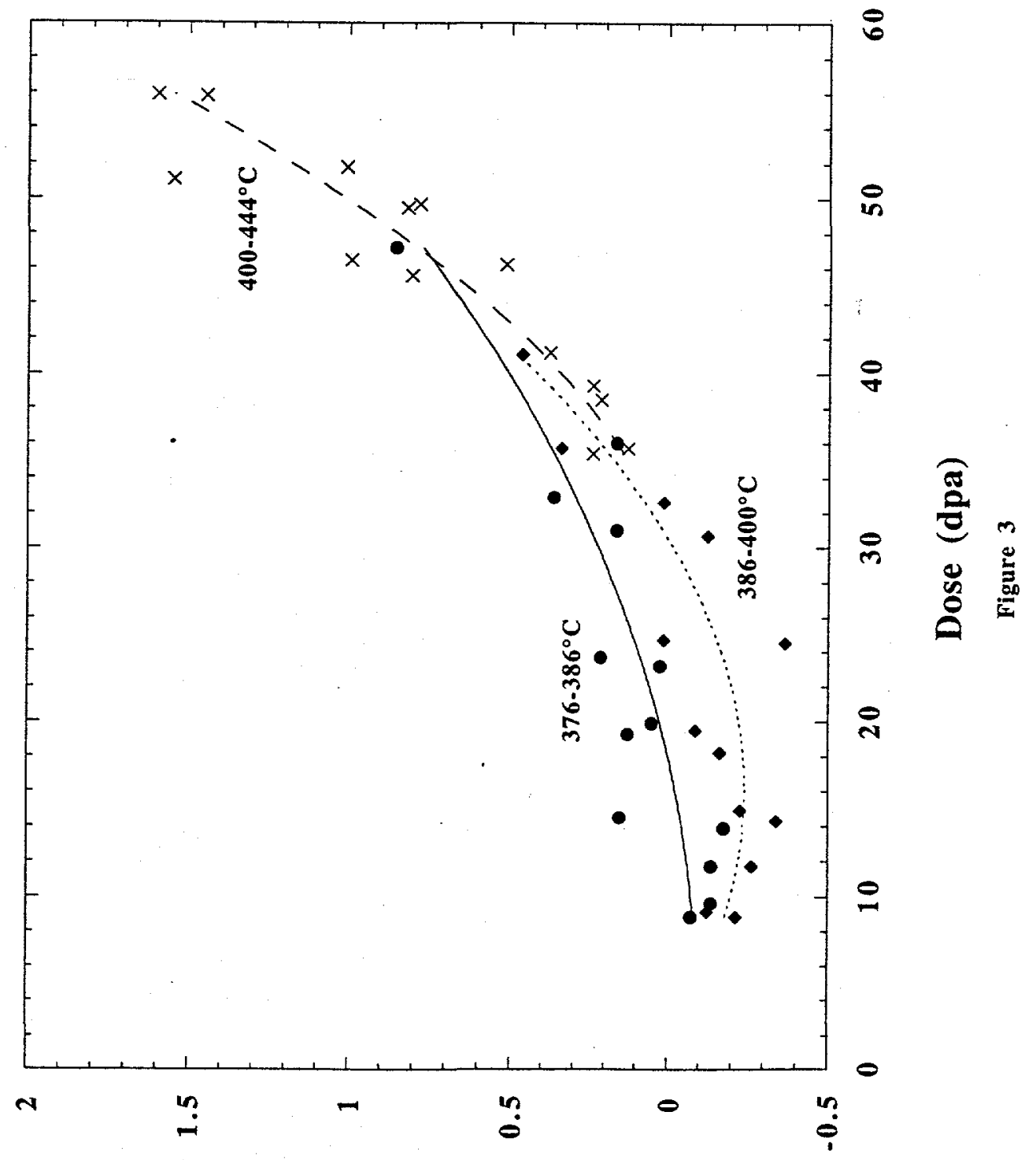

(\%) 8ิu! 


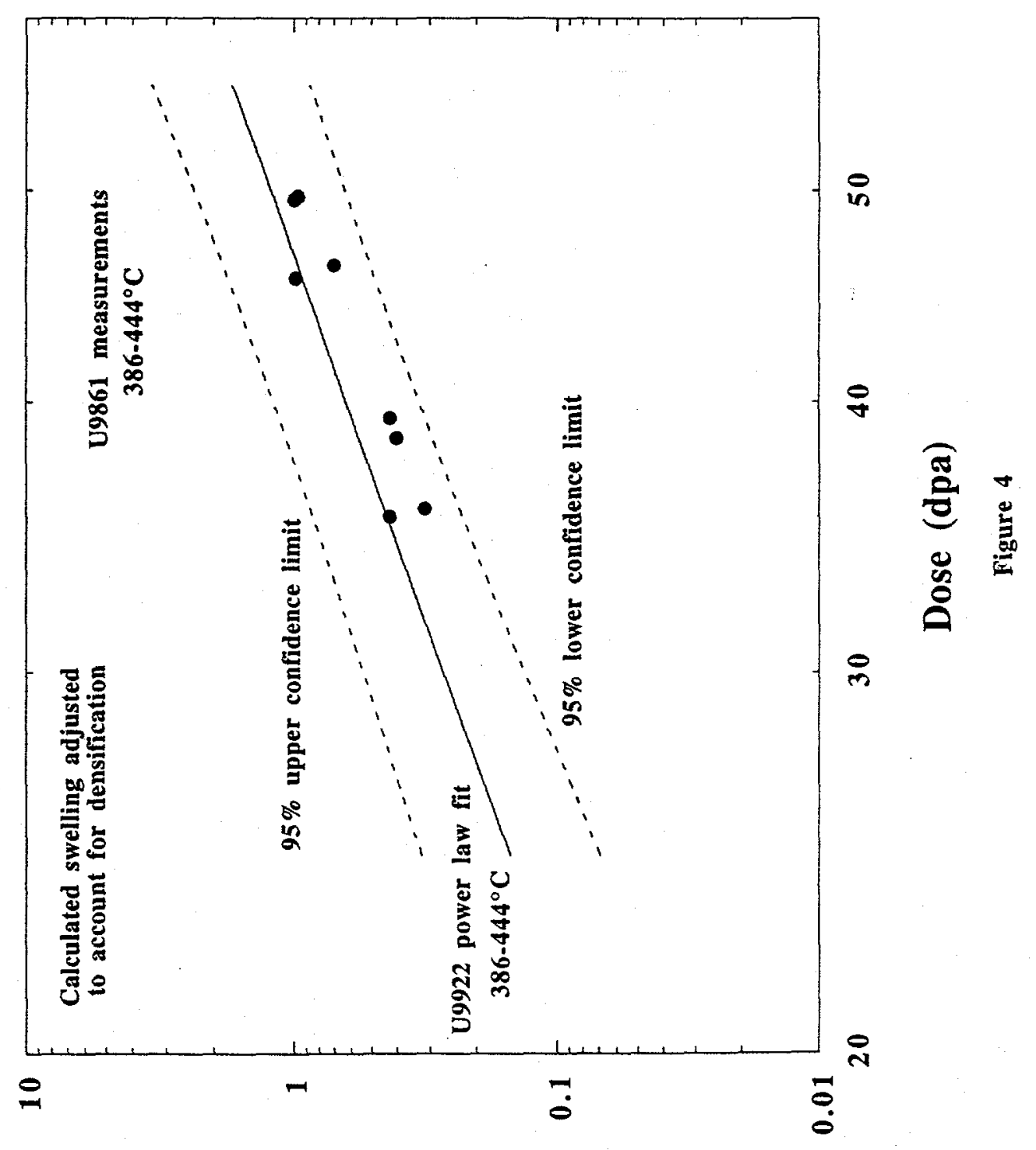

(\%) 8u!nəмS 


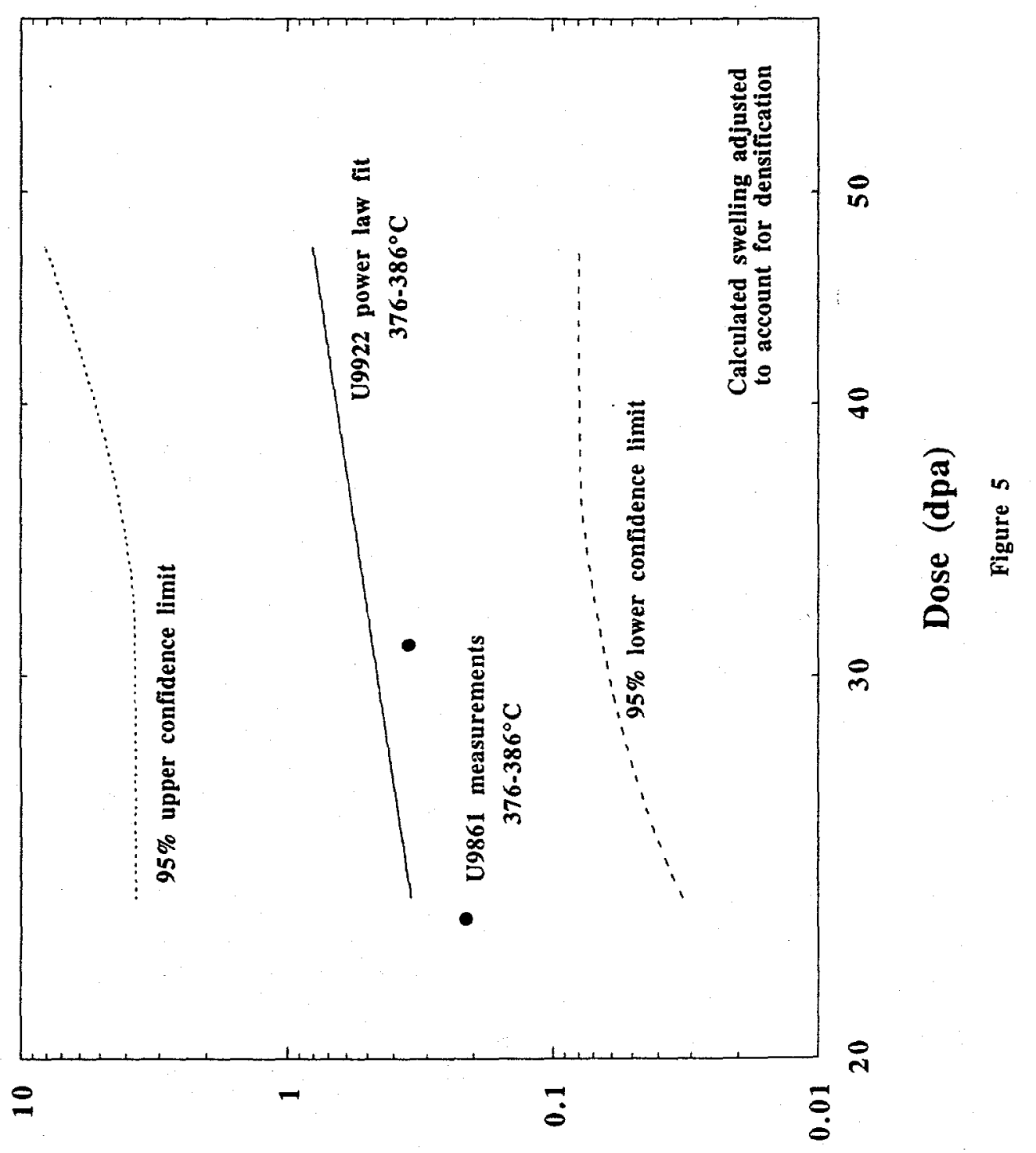

(\%) 8ิu!!ाวMS 


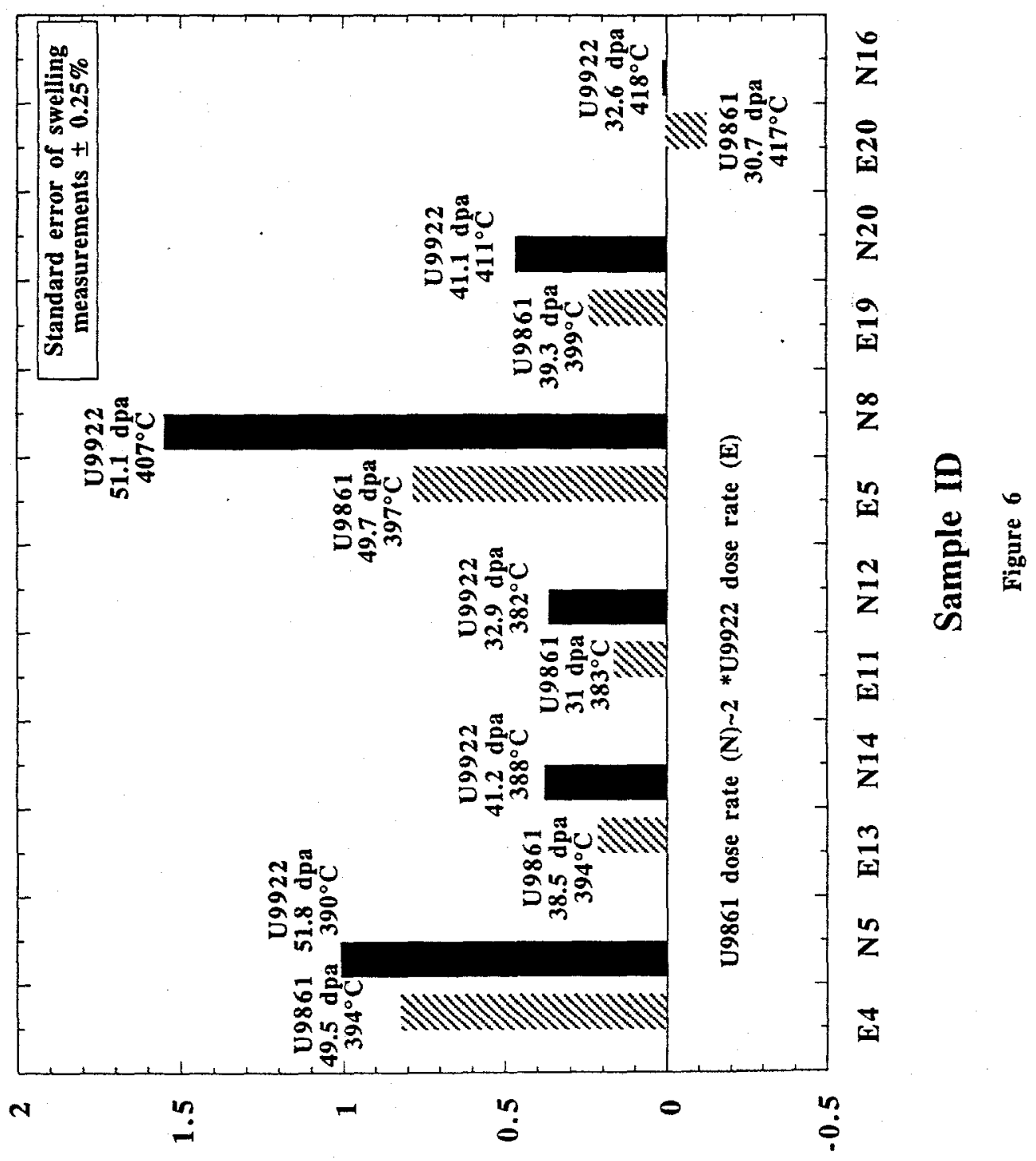

(\%) 8u!ाাวMS 


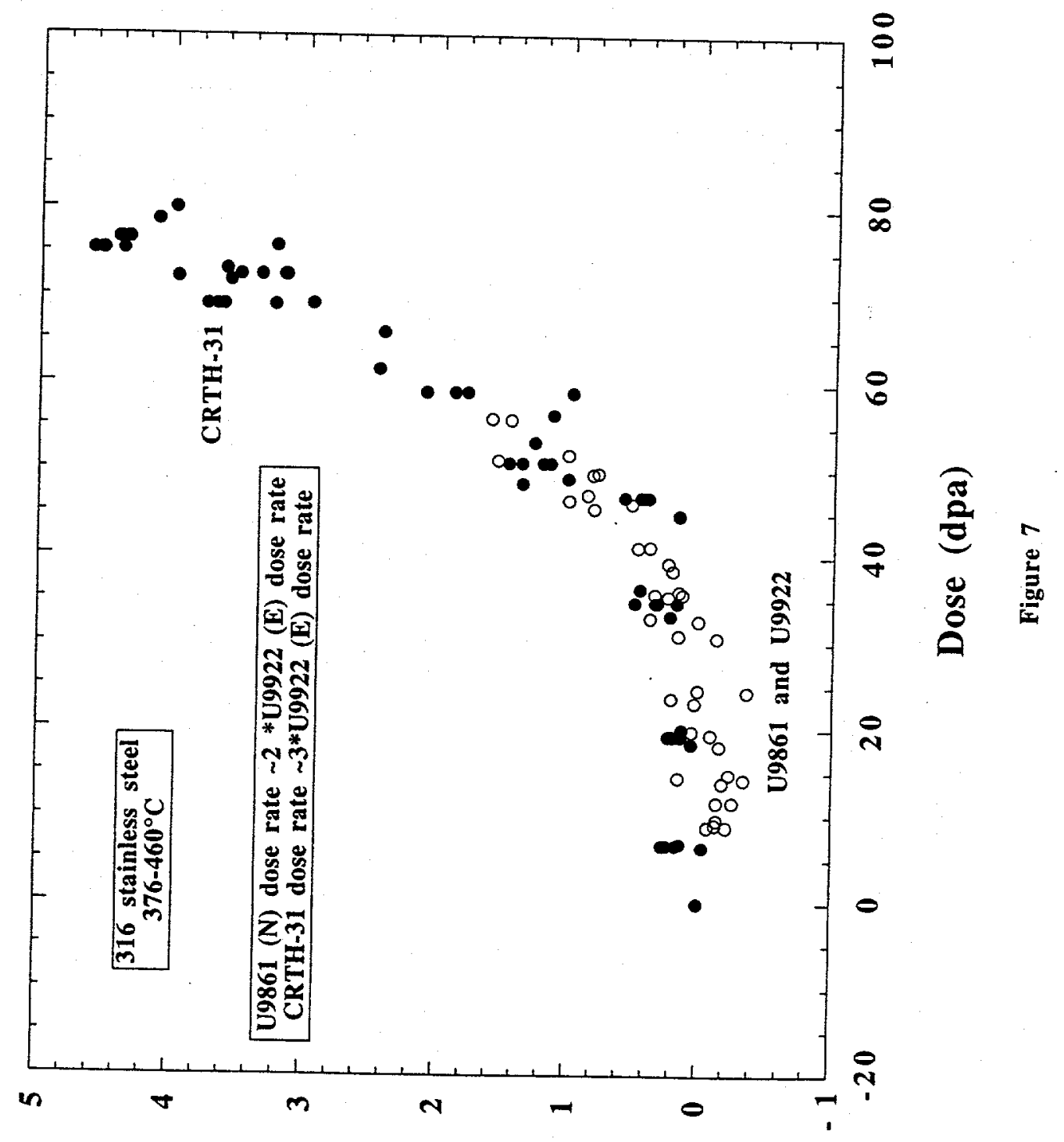

(\%) 8ิu!̣IวMS 